\title{
La gripe hespanhola: memórias histórico-literárias na ficção amazônica do século XX
}

\section{La gripe hespanhola: historical-literary memories in Amazonian fiction of the century XX}

Francisco Pereira Smith Júnior - Professor permanente do Programa de Pós-Graduação em Linguagens e Saberes na Amazônia (PPLSA) da Universidade Federal do Pará (UFPA). Coordenador do Grupo de Estudos de Literatura Comparada do Nordeste Paraense (GELCONPE). Coordenador do Grupo de Estudos de Letramento Literário e Formação Interdisciplinar (GELLIFI). E-mails: fsmith@ufpa.br ou fransmithj@gmail.com

\section{Resumo}

Este artigo ter por objetivo fazer uma análise da crônica Preces, Remédio Contra Epidemia, de Campos Ribeiro, obra de 1942. O ambiente apresentado por esta narrativa serão as memórias do início do século XX, mais precisamente os fatos relacionados à epidemia da gripe hespanbola ocorrida na cidade de Belém do Pará, localizada ao norte do Brasil. O texto apresenta ao leitor a possibilidade de uma reflexão a respeito do auge da epidemia da gripe espanhoa na metrópole amazônica após a economia da borracha e assim permite revisitar os dramas da população naquela época. Para essa discussão foram trazidos os textos literários de Ribeiro (2005), Mendonça (2002) e Meira (1976). Para a discussão teórica trago os estudos de Bosi (1994) e Abreu Júnior (2018).

\begin{abstract}
This article aims to make an analysis of the chronicle Praces, Remédio Contra Epidemia, by Campos Ribeiro, book of 1942. The environment lived in the narrative will be the memories of the beginning of the 20th century, more precisely the facts related to the epidemic of the hespanhola that occurred in the city of Belém do Pará. The text presents the reader with the possibility of reflecting on the peak of the epidemic in the Amazonian metropolis after the times of the rubber economy and allows revisiting the dramas of the population of that time. The literary texts of Ribeiro (2005), Mendonça (2002) and Meira (1976) were brought to this discussion. For the theoretical discussion I bring the studies of Bosi (1994) and Abreu Júnior (2018).
\end{abstract}

\section{Palavras-chave}

Epidemia. Espanhola. Memórias. Belém.

\section{Keywords}

Epidemic. Spanish. Memories. Belém. 


\section{INTRODUÇÃO}

A complexidade da Amazônia, nas suas dimensões geográficas de pluralidade étnico-cultural, tornou-se o cenário fértil para a ficção brasileira. $\mathrm{O}$ ambiente pitoresco e exótico da região também foram inspirações de narrativas de viajantes do século XVI, como os textos de Carvajal ${ }^{1}$ que narrou suas aventuras e construiu sua leitura da Amazônia na ficção historiográfica brasileira.

Já o início do século XX, a ficção amazônica nos trouxe uma Amazônia urbana e caótica que se agigantava em meio às heranças da Belle Époque, uma região que se confrontou não só com a riqueza, mas também com a pobreza. O reflexo disso está nos problemas vividos pela população amazônica, que por vezes, pagou com a própria vida por não ter acesso a direitos fundamentais, como a saúde pública. Assim, o século XX vivenciou momentos de uma Amazônia problemática com falta de saneamento básico, marginalização, violência, revoltas e muitas doenças. Alguns exemplos desse "caos amazônico" podem ser lidos em alguns trechos de obras de escritores da Amazônia, como Abguar Bastos, Benedicto Monteiro, Dalcídio Jurandir, Eneida de Moraes dentre outros.

Ao tratar de uma Amazônia específica, neste artigo ${ }^{2}$ fez-se a escolha pela Amazônia paraense. Para isso, será feita a retomada no tempo à literatura desta região. Optou-se por investigar inicialmente as obras Memórias do quase ontem de Octavio Meira (MEIRA, 1976) e Rastos e marcas das passadas minhas pelas sendas e avenidas da vida de Danilo Virgílio Mendonça (MENDONÇA, 2002), mas será dada maior atenção para a terceira obra Preces, Remédio Contra Epidemia, de Campos Ribeiro (RIBEIRO, 1942).

A primeira obra é uma raridade da literatura da Amazônia, já com edição esgotada e com poucos exemplares disponíveis para leitura, o texto apresenta ao leitor uma cuidadosa descrição de episódios políticos, sociais e culturais relativos ao estado do Pará do século XX. Dentre aos vários episódios históricos relacionados à vida da população paraense, o autor traz uma discussão de interesse para este estudo, as moléstias no início do século XX.

Em Memórias do quase ontem, ao comentar as dificuldades da sua infância, o narrador relembra os dias que havia sido acometido pelo sarampo, quando "um dia adoeci. Febre forte, dores no corpo. De noite, delirava e chamava pela Jacinta

Padre dominicano espanhol que realizou viagens pelos rios da Amazônia no século XVI.

Este artigo teve apoio da CAPES e surgiu a partir de uma produção conjunta com o bolsista Carlos Geovane da Costa Araújo, bolsista CNPQ, vinculado ao Grupo de Estudos de Literatura Comparada do Nordeste Paraense (GELCONPE). E-mail: cgcarlosgeovane@gmail.com 
que esse tempo ainda vivia". "Veio o médico o Dr. Pondé, um baiano de cor um pouco queimada, pediatra afamado na terra. E diagnosticou: sarampo" (MEIRA, 1976, p. 125).

O cenário de doenças no início do século XX narra também uma Amazônia frágil, cidades vulneráveis à presença de doenças que não se sabiam qual sua origem. Os diagnósticos eram variados, a origem das moléstias, não se compreendia, mas cogitava-se a possibilidade da praga ter sido trazida pelos imigrantes europeus que se instalaram na cidade, atraídos pelas promessas de trabalho na Amazônia.

O narrador de Memórias do quase ontem revela que em $1918^{3}$, assistiu ao "espetáculo horroroso" da chegada da gripe espanhola, e confuso sem saber a razão de tamanho horror que se alastrava pela cidade de Belém do Pará. "Foi quando chegou a Belém, no ar, no porão dos navios, quando ventos gerais que às quatro horas da tarde nos visitam, a gripe espanhola, a 'influenza', que atingiu a todos os Continentes, como uma sentença de morte irreversível" (MEIRA, 1976, p. 136).

A cidade foi destroçada por esse vírus. Por melhor que o governo pudesse socorrer a população, nada adiantava. Os carros fúnebres, que costumavam levar o cadáver dos indigentes falecidos, passaram a ser utilizados no transporte do corpo de quantos, ricos ou pobres, tivessem a mesma sorte, uma, duas, três, vinte ou cem vezes. No cemitério de Santa Izabel ficavam eles insepultos (MEIRA, 1976, p. 136).

Belém era acometida por um mal que assustava a sua população, as ruas tornaram-se vazias, pouco movimento, foram anos de recessão, poucas construções e pobreza que assolava uma cidade triste. Em Memórias do quase ontem há relatos das perdas de pessoas próximas do narrador e chama atenção para a lembrança da morte da mãe de Eneida de Moraes ${ }^{4}$ e a triste memória das despedidas. As vítimas não possuíam classe e nem cor, as notícias "corriam" pela vizinhança e se sabiam rapidamente informações de mortes de pessoas importantes por toda a cidade, desde políticos, intelectuais e até militares ligados ao governo.

3 As infecções ocorridas no início do século XX no Brasil eram constantes, já que muito antes de 1918, a influenza já era um problema conhecido dos brasileiros, esta se configurava, assim como o tifo, a malária e a febra amarela, como uma das mais graves doenças trazidas pelos colonizadores europeus e se espalhou por todo o território brasileiro, dizimando populações nativas.

4 Jornalista, escritora, militante política e pesquisadora paraense. Eneida é sempre descrita em relatos de amigos e parentes como uma mulher forte, corajosa, audaciosa e inteligente. Vivenciou a ditadura militar e lutou pelos mesmos ideais democráticos de personalidades como Olga Benário. 
Morávamos no Largo da Memória e vimos inúmeros casos ocorrerem em nossa vizinhança. $\mathrm{Na}$ casa do coronel Raimundo Pereira Brasil, na residência do Sr. João Câncio Fernandes, onde morava seu irmão Childerico Fernandes, ao lado direito e esquerdo de nossa moradia onde vivia o dr. Hugo Napoleão e a família Horta, houve a ocorrência repetida da gripe pneumônica, que a todos assaltava.

Nesse momento ocorreram duas mortes profundamente impressionantes: Dona Julia Miranda Castelo Branco esposa do Sr. João Castelo Branco e a filha do senador Jose Porfírio de Miranda e o de dona Júlia Costa, esposa do comandante Guilherme Costa, que dirigia um navio fluvial na Amazônia. Morreram no mesmo dia.

A primeira delas morava na Travessa a Quintino Bocaiúva, em casa hoje demolida, e era mãe de Maria, Medrado, Nahir, Jose Miranda Castelo Branco, João de Miranda Castelo Branco e Orlando de Miranda Castelo Branco, que ficaram bem pequenos, com o pai aflito e dentro de pouco tempo morria também. Lembro-me do carro mortuário de primeira classe, com quatro cavalos, ajaezados, com plumas negras na cabeça cobertos por mantilhas rendadas. Trazia dois cocheiros comas roupas fúnebres e cobertos por uma cartola. Sua morte, vítima de "influenza" deixando toda a cidade surpresa (MEIRA, 1976, p. 136-137).

As cenas de cortejo fúnebre se multiplicavam, não só em cidades como Belém, mas no país inteiro, um estado de colapso coletivo. Outras cidades também foram violentamente atacadas pelo vírus devastador. No caso do Rio de Janeiro (1918), a doença evolui ao ponto dos funcionários do Cemitério S. F. Xavier (Caju) decidirem entrar em greve, pois não estavam dando conta da demanda de corpos a serem sepultados.

Figura 1 - Gazeta de Notícias - A devastação da epidemia

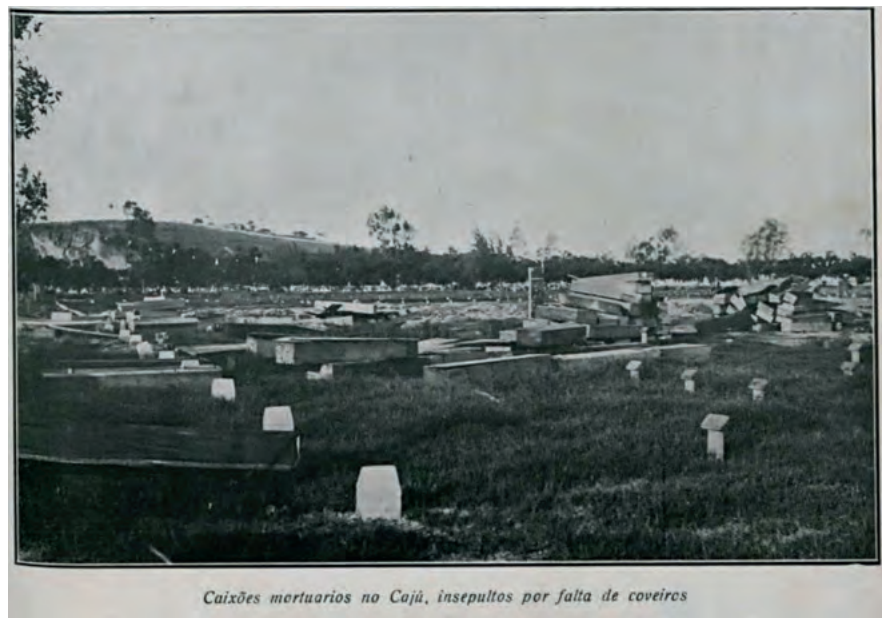

Fonte: O Novo... (2020). 
Em Belém, a memória da morte da mãe de Eneida de Moraes assustou pela rapidez pela qual a vítima foi acometida. Os velórios tornavam-se a última despedida e por vezes pareciam eventos, dependendo da importância da vítima da moléstia. Havia a necessidade de criar em pouco tempo um protocolo de cuidados para enfrentar a doença, assim cada vez mais se tornou reduzida a possibilidade de ocorrerem às últimas homenagens às vítimas da peste.

Julia Costa morava à travessa Benjamin Constant esquina da Boaventura da Silva, num palecete, que depois foi utilizado pelo Banco de crédito da Amazônia para a sua modelar escola.

Era mãe de Eneida, a nossa poetisa e cronista saudosa, de Manoel Costa, o "Manduca", da nossa intimidade e o Guilherme Costa, o "Guilito" e da formosa Nereida, que os anos já levaram. Morreram vítimas do mesmo mal. Seus funerais foram de primeira classe toda a cidade, que não estava enferma compareceu.

Em nossa casa o mal não encontrou guarita, tantas crianças, já éramos seis e vivíamos a entupir os narizes com "rinosol" e "mistol" como preventivos contra a contaminação e assim ficamos livres de todo o mal (MEIRA, 1976, p. 137).

A higienização parecia o método mais eficaz para evitar que o vírus da gripe espanhola não se proliferasse pela cidade, a administração de Belém tentou evitar ao máximo o contágio da sua população, criando medidas de contenção e investigação sobre sua origem, mas as notícias da época não eram as melhores, pois o vírus parecia tomar conta de toda a população.

Em avaliação a algumas das proposições do novo comunicado das autoridades sanitárias, observa-se que a primeira medida não possui nenhum caráter preventivo, mas, sim, tem por objetivo apresentar ao público a natureza da doença. Nota-se ainda que os mosquitos desaparecessem do rol de possibilidades de transmissão, mostrando que os médicos, se não tinham certeza do que ocorria, já tinham um consenso maior sobre a doença em si. Pela quinta medida, percebe-se que os internamentos ou isolamentos dos casos não eram obrigatórios naquela etapa da epidemia. Já a sexta medida transformava a gripe em uma doença de notificação, compulsória, adotada para tentar mapear o aparecimento dos casos novos (ABREU JUNIOR, 2018, p. 114).

O comércio local também buscou se adaptar àquela realidade assustadora, os ambulantes criavam alternativas diversas para evitar o contágio e preservar os seus negócios. A lembrança do narrador rememora cenas sanitárias de uma cidade assustada e que buscava por soluções imediatas para o problema da epidemia. $\mathrm{Na}$ qual dizia: 
Lembro que o serviço de limpeza pública era feito a tração animal. A uma hora da tarde. Invariavelmente desciam da 22 de junho, hoje Alcindo Cacela, os carros puxados e cavalo e bois. Vinham pela Avenida Nazareth até o largo da memória, onde morávamos, desciam pela Quintino Bocaiúva e se perdiam lá adiante. Parecia uma fila de saúvas: dezenas e dezenas de carros, todos verdes, com o clássico L.P de um lado e I. M. B do outro, com os animais barulhentos, com o som dos guisos que traziam nos arreios. A cidade limpava-se apesar de toda a crise.

O leite era vendido na madrugada na porta das casas. O leiteiro trazia as próprias vacas e extraia o leite quanto o freguês queria, na sua própria frente. Depois isso acabou. Vieram os vasilhames padronizados e veio também a água a se misturar ao leite, e os fiscais e veio a corrupção e o resto (MEIRA, 1976, p. 137).

Diante do exposto, convido o leitor a pensar. O que aprendemos com esse passado? O texto de Octavio Meira e a crônica de Campos Ribeiro (que será analisada) nos faz reviver o mesmo cenário em pleno século XXI com a chegada de um vírus mortal chamado covid-19, ou seja, um século depois, vivenciou-se o mesmo cenário de desespero e fragilidade da saúde pública Novamente todas as classes sociais estão diante de um dos confrontos mais desesperadores de sua geração.

Mas o que ficou de aprendizado da gripe espanhola? Para que serve o passado?

O passado conserva-se e, além de conservar-se, atua no presente, mas não de forma homogênea. De um lado, o corpo guarda esquemas de comportamento de que se vale muitas vezes automaticamente na sua ação sobre as coisas: trata-se da memória-hábito, memória dos mecanismos motores. De outro lado, ocorrem lembranças independentes de quaisquer hábitos: lembranças isoladas, singulares, que constituiriam autênticas ressurreições do passado (BOSI, 1994, p. 11).

A preservação de uma memória coletiva parece não ter se mantido um século depois pela população brasileira. A lembrança daquilo que não foi bom e o registro dos males do passado parecem ter se dissipado em meio à propagação ao avanço da tecnologia e a globalização. Quando se deveria haver mais informação, passamos a ver um novo cenário de horror com a chegada de um vírus mortal aos "moldes do passado".

Com mais trezentos mil mortos em todo o país pelo vírus da covid-19, o que se percebeu foi o negacionismo de órgãos públicos federais tratando a moléstia da doença como uma "gripezinha qualquer". Sob a alegação de que a economia do país não poderia parar, somado a reação tardia diante do perigo do vírus, o governo acabou não dando os direcionamentos equivocados para o 
enfrentamento da doença. Essa atitude de negação ocasionou em milhões de mortes de brasileiros em estados da Amazônia, como o Amazonas e Pará, estados esses que contaram com problemas pontuais pelo fato do vírus da covid-19 ter sofrido mutações e apresentar uma nova $c e p a^{5}$ mais contagiosa e mortal.

O cenário de desespero da população brasileira diante do vírus da covid-19 em quase nada mudou do que ocorreu com a gripe espanhola na Amazônia, com exceção do número bem maior de vítimas. Um século depois as principais medidas de contenção do vírus, como o distanciamento social, uso de máscara e as higienizações das mãos parecem ainda não serem compreendidas pela população brasileira como alternativa mais sensata para se preservar do contágio do vírus. O preço por essa recusa levou a população a um ritmo assustador de mortes pela doença que fez com que as vítimas saíssem do anonimato e ganhassem "rostos familiares", contribuindo assim para o retorno de uma sensação de horror e medo na população em pleno século XXI.

Assim, a covid-19 levou a população brasileira a optar por dois caminhos um do negacionismo e o outro da ciência, colocando-se em meio a uma escolha quase que política. O sentimento de negar a presença do vírus levou a boa parte da população a acreditar em uma pós-verdade que iria a defesa de uma desconstrução da prova científica. Enquanto isso se via uma ciência e órgãos de comunicação preocupados em informar e alertar a população para o perigo.

Essas reflexões se fazem presentes aqui neste texto pelo fato de vivermos atualmente o mesmo cenário do passado, com situações semelhantes no mundo e principalmente no Brasil. O vírus, para a sociedade brasileira, tornou-se um mal que parece não ter mais fim, principalmente pela dificuldade apresentada de se conseguir em tempo hábil um número significativo de vacinas para imunizar a população. No entanto, deixar-se-á essa conversa para o momento de conclusão deste artigo.

Dando continuidade a análise literária, a segunda obra a ser estudada será Rastos e marcas das passadas minhas pelas sendas e avenidas da vida de Danilo Virgílio Mendonça (MENDONÇA, 2002), que também traz ao leitor o cenário da gripe espanhola no início do século XX. O texto relata memórias tristes que o cronista desejava esquecer, mas as marcas foram tão significativas na história da população paraense que "pareceu" ser um tempo de experiência para tentar não errar mais. Segundo Bosi (1994) a lembrança é a sobrevivência do passado.

\footnotetext{
Genomas com mutações semelhantes formam variantes ou linhagens de vírus que podem ser mais contagiosos ou mortais.
} 
O passado, conservando-se no espírito de cada ser humano, afiara a consciência na forma de imagens-lembrança.

A narrativa Rastos e marcas das passadas minhas pelas sendas e avenidas da vida revela uma cidade traumatizada pela chegada ${ }^{6}$ de um vírus avassalador em meio ao caos de uma cidade que crescia aos moldes europeus urbanos. As lembranças da imigração, na obra, revelam a ligação entre o vírus e a pandemia e descrevem os horrores da presença da gripe espanhola em Belém do Pará (MENDONÇA, 2002).

Naquele momento, os vários imigrantes nacionais e de outras nacionalidades representaram uma ameaça a higiene da cidade que não dava conta de alojar tantas famílias que chegavam em grande quantidade possivelmente contaminadas ${ }^{7}$ "Nessas levas de imigrantes a família Ribeiro (descartada de Duda que não quis descer os barrancos do Amazonas), chegou a Belém, sobrevivente da Odisséia dos seringais, decorria então o ano de 1917” (MENDONÇA, 2002, p. 66).

Em conseqüência da gripe espanhola perdi minha mãe, em um dia o marido e no dia seguinte o filho Eudes. Contava-me relembrando aqueles anos distantes, que houve em ruas de Belém, que fecharam todas as casas pela morte de todos os seus moradores. Os cadáveres eram recolhidos, pelos carros da intendência, à boca da noite. Levados para os cemitérios eram enterrados em valas comuns sem uma identificação sequer (MENDONÇA, 2002, p. 68-69).

O ambiente de uma cidade contaminada e exposta a um vírus tornou a população cada vez mais vulnerável as possibilidades de contaminação, pois situações de fragilidade deixaram a sociedade belenense cada vez mais frágil. Segundo Smith Júnior (2012) o número significativo de imigrantes portugueses, italianos e espanhóis na Amazônia fizeram da capital paraense "uma babel" com problemas de ordem sanitária e de segurança, com o crescimento acelerado de Belém e a falta de uma política de planejamento urbano, o centro da cidade "via" velhos casarões abandonados se transformarem em pensões e cortiços para receberem imigrantes de todas as partes do Brasil

6 Segundo Mendonça (2002), Karina Pastore, em artigo publicado pela revista "Veja”, em 1997, intitulado Caçadores de Virus e com ilustrações de vírus HIV e Ebola, destaca que a doença da gripe espanhola não surgiu na Espanha, como sempre se pensou, e sim nos Estados Unidos. O primeiro caso registrado foi em Camps Funston, no Kansas, em março de 1918. Tudo indica que a pandemia de 1918 começou quando o fazendeiro pegou a gripe dos porcos do seu chiqueiro que, por sua vez, a apanharam ao comer os dejetos dos patos selvagens da região.

7 Segundo Abreu Júnior (2018) a origem do vírus permanece controversa. Potter (2001, p. 575) aponta para uma possível origem chinesa. Entretanto, como os primeiros surtos divulgados teriam ocorrido nos Estados Unidos, em Detroit, na Carolina do Sul, e na prisão de San Quentin, em março de 1918, autores como Crosby (1989, p. 4-5) apoiam a teoria de que a influenza tenha origem norte-americana. 
e do mundo. Sem contar com a presença marcante de estrangeiros em vilas organizadas por imigrantes, que se amontoavam a convite de parentes e amigos deixando a população exposta a gripe espanhola. Muitos diziam se instalar provisoriamente até encontrar um lugar fixo para moradia, mas acabavam ficando de forma permanente nesta situação. Assim, o início do século XX foi marcado por problemas sociais na capital paraense que passaram a chamar atenção do Consulado Espanhol do Pará.

As aglomerações urbanas e péssimas condições de saneamento básico fizeram com que a gripe espanhola se espalhasse por Belém. A dificuldade de encontrar uma vacina, ou uma cura para a doença possibilitou um cenário de muitas mortes, principalmente dos mais pobres que não tinham condições de manter a própria higiene pessoal. Neste ambiente, imigrantes "ainda não contaminados" também se tornavam vulneráveis ao contágio.

Ao tratar de uma Amazônia específica, que aqui será chamada de "Amazônia paraense", este artigo relembra a produção de escritores que também trataram de um ambiente insalubre da cidade de Belém, onde este foi o espaço das peripécias de suas personagens de ficção. Um exemplo disso é o escritor Dalcídio Jurandir, escritor marajoara que soube trazer para sua literatura uma escrita que estava além do seu olhar regionalista, pois soube interpretar os problemas sociais da região. Na obra Passagens dos Inocentes (JURANDIR, 1984), o narrador nos faz retomar as experiências de um jovem chamado Alfredo, que se vê diante da realidade de uma cidade complexa e cheia de problemas sociais, com dificuldades de urbanização, falta de saneamento básico e de saúde nos bairros mais periféricos da cidade. O personagem Alfredo defronta-se com uma realidade totalmente diferente daquela que construiu no seu imaginário interiorano infantil, vendo suas expectativas se perderem em meio a uma experiência frustrante com a capital paraense. Mas a análise sobre a obra deste escritor deixar-se-á também para outro momento.

Ao pensar sobre essa complexidade do espaço amazônico na literatura brasileira, como um campo fértil de possibilidades de criação, o objetivo deste artigo é trazer para ao conhecimento do leitor, reflexões e apontamentos sobre as memórias da gripe espanhola, ocorrida no início do século XX, em específico na crônica Preces, Remédio Contra Epidemia na obra intitulada Gostosa Belém de outrora... de José Sampaio de Campos Ribeiro (RIBEIRO, 2005), sem deixar de considerar a importância do diálogo com as obras Memórias do quase ontem de Octavio Meira 
(MEIRA, 1976) e Rastos e marcas das passadas minhas pelas sendas e avenidas da vida de Danilo Virgílio Mendonça (MENDONÇA, 2002). Assim, percebe-se que todas três obras revelam o surgimento da gripe espanhola ${ }^{8}$ em pleno cenário desastroso da primeira guerra mundial e narram ao mundo a triste realidade de uma doença desconhecida que fez milhares ${ }^{9}$ de vítimas na Amazônia e ao redor do mundo.

\section{A PANDEMIA E O MEDO: MEMÓRIAS DA CIDADE DAS MANGUEIRAS}

A terceira obra em análise, na qual este artigo dará maior atenção, será Gostosa Belém de Outrora (1966), do escritor José Sampaio de Campos Ribeiro ${ }^{10}$ (RIBEIRO, 2005). O Livro reúne uma série de crônicas que remontam o cotidiano da cidade de Belém do Pará, do início até meados do século XX. Dentre os relatos apresentados de uma forma memorialística, a crônica Preces, Remédio Contra Epidemia retrata o clima da capital do Pará, no período da Gripe Espanhola que ocorreu na cidade. Assim, o autor por meio de vários personagens e relatos, apresenta ao leitor os dramas de uma sociedade amazônica no início do século XX.

No início da narrativa observa-se que o narrador de Campos Ribeiro destaca o nome do surto viral colocando aspas no termo, "espanhola". Talvez seja pelo fato de que a grafia em alguns lugares inicie com a letra " $H$ ". Além disso, o surto viral foi associado à Espanha, no entanto, segundo relatos a moléstia surgiu em bases militares dos Estados Unidos, sendo atrelada aos espanhóis, devido sua posição de neutralidade na Segunda Guerra Mundial e porque o país noticiava constantemente fatos sobre a enfermidade. Ademais, cabe ressaltar que em meio a esse clima de conflito a doença se expandiu por vários países, como por exemplo, o Brasil, afetando cidades como o Rio do Janeiro ${ }^{11}$, uma das mais atingidas na época, sendo apresentada inclusive logo nas primeiras linhas da crônica paraense de Campos Ribeiro.

\footnotetext{
8 Apesar de o nome referenciar à Espanha, boa parte dos estudos científicos afirma que a infecção surgiu em plena primeira guerra mundial, nos EUA.

9 Estima-se que o número de mortos representa mais mortes do que o montante provocado pelas duas grandes guerras juntas e mais do que o número de mortos pela AIDS em 40 anos.

10 Jornalista de longa vivencia nos jornais diários da terra, rebuscou no cofre da memória tipos e episódios que o tempo não conseguiu esboroar. O escritor teve grande destaque ao lado de escritores como Bruno de Menezes, Clóvis de Gusmão, Jacques Flores e Abguar Bastos.

11 Cenário muito parecido com atual situação de vítimas da covid-19.
} 
Figura 2 - Jornal Gazeta

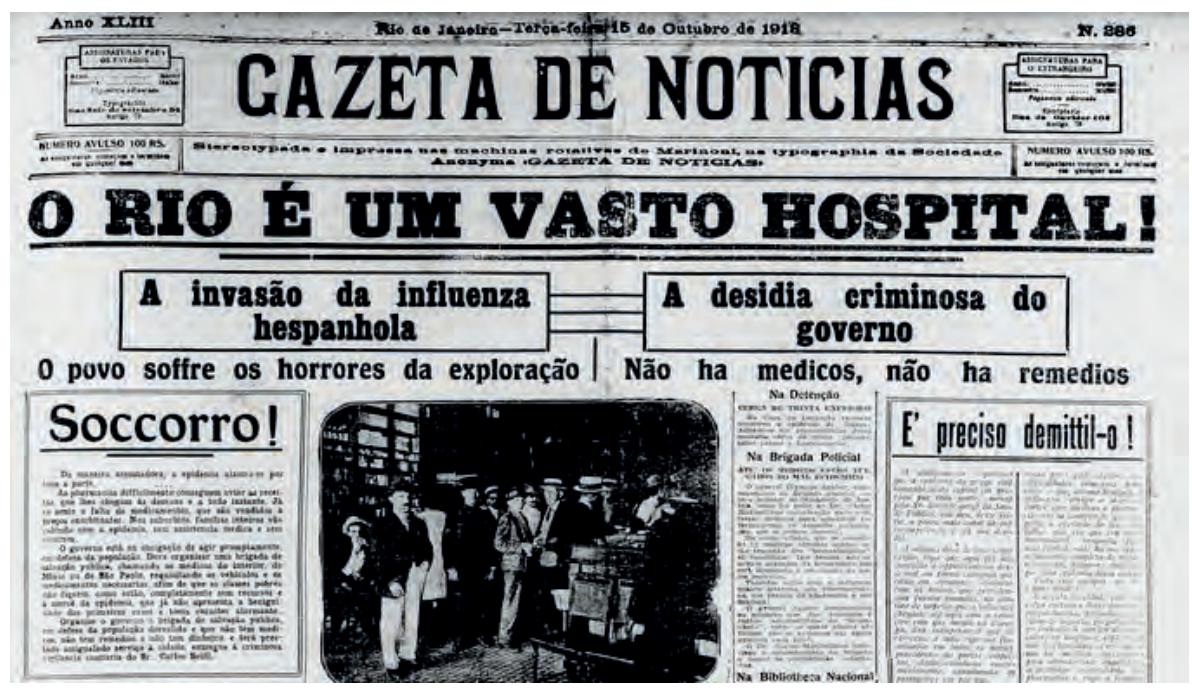

Fonte: Lucena (2020, p. 1).

Nesse seguimento, o estado de calamidade em que a cidade do Rio de Janeiro passou nesse período, foi posto no texto da Gazeta de notícias, no qual dizia que "nos seus aspectos sinistros de calamidade pública, a doença estava deixando até, lá pelo Rio de Janeiro, cadáveres insepultos porque morrido havia todos os coveiros" e outros evitavam ir trabalhar. Pode-se perceber nessa passagem alusiva, como a capital federativa brasileira na época se encontrava, há relatos de que o número de vítimas era tão grande que havia vários cadáveres nas ruas, devido ao colapso do sistema de saúde e funerário. Segundo algumas estimativas, há relatos que dizem que a moléstia pode ter causado a morte de pelo menos 15 mil pessoas no Estado, mas não se tem certeza desses números.

O autor Campos Ribeiro (2005) nas linhas seguintes da narrativa faz um paralelo da situação endêmica desse centro urbano com a cidade de Belém do Pará, descrevendo, “também nesta Santa Maria de Belém, àquele tempo, ceifou milhares de vidas, enlutou centenas de famílias" (p. 71).

Em meados do ano de 1918, Belém ainda “respirava ares" da Belle Époque ${ }^{12}$, período advindo da economia da borracha que ocorreu não só no maior centro

12 A chamada Bela Época na língua francesa (Belle Époque), teve seu início no século XIX e durou até a eclosão da primeira guerra mundial. Foi considerado como um período de muita riqueza, inovação e beleza em vários países da Europa, o que acabou espalhando várias influências para outros países. No Brasil, várias cidades foram fortemente influenciadas pelo estilo, especialmente os centros urbanos amazônicos como Belém e Manaus, que tiveram um crescimento considerado devido a extração de borracha, o que gerou muitas mudanças principalmente na arquitetura dos centros urbanos. O período na capital do Pará durou até meados de 1915, por causa da decadência do ciclo da borracha. 
urbano paraense, mas em outros centros, como Manaus, capital do Estado do Amazonas. Mesmo esse período apresentando declínio desde 1910, o clima e a ideia de desenvolvimento da Amazônia ainda era externado pelos políticos, o que se refletia na população o sentimento de que os estados possuíam grandes recursos financeiros.

Vale ressaltar que com o processo de modificação da arquitetura da urbe de Belém, inspirada nos traços parisienses, os populares com menor poder aquisitivo eram realocados para espaços distantes do centro. Locais esses, que não possuíam boas estruturas para uma moradia adequada, faltando necessidades básicas, como por exemplo, saneamento básico.

Figura 3 - Arquitetura de Belém na época da Belle Époque

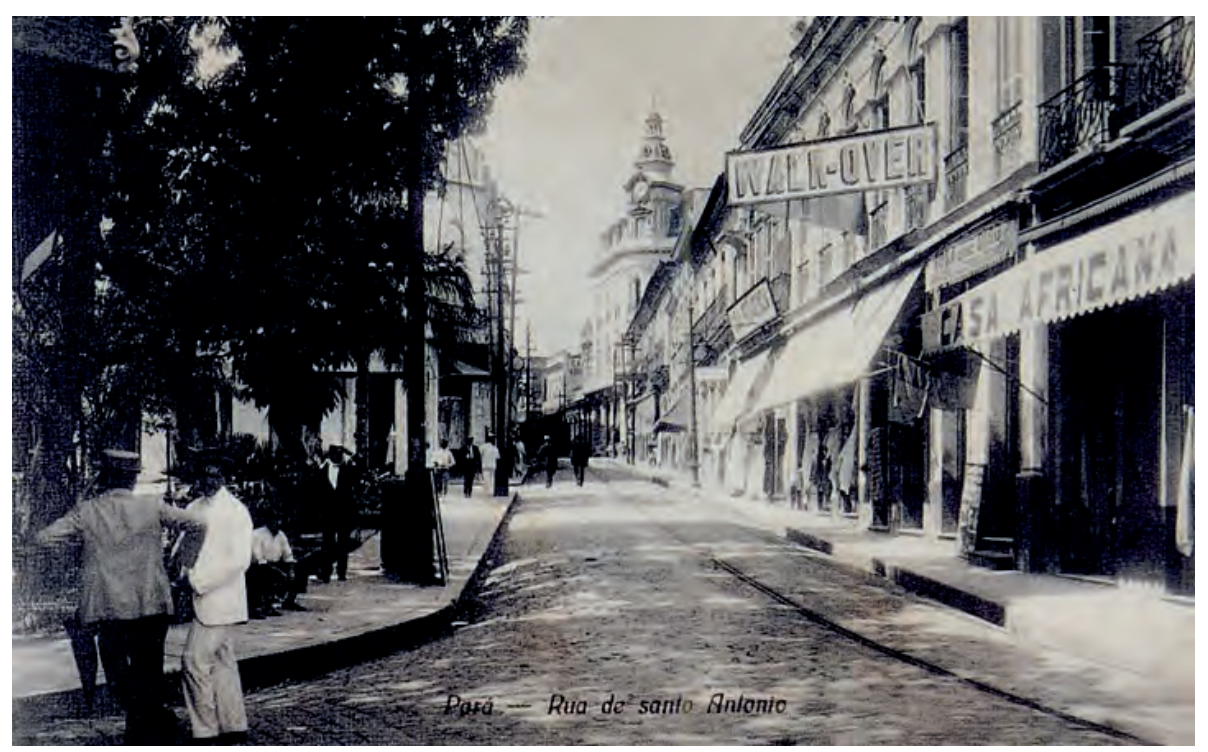

Fonte: Viégas (2011, p. 2).

Nessa continuidade, a realidade das diferenças entre as classes sociais tornava-se cada vez mais nítida, mesmo com as estratégias governamentais em esconder o declínio da economia da borracha, que posteriormente seria revelado pela pandemia que assolaria o município. Ademais, no segundo semestre de 1918, a gripe espanhola já assolava muitos brasileiros, principalmente aqueles de cidades portuárias como Rio de Janeiro, Salvador e Recife.

A sede do Pará, conhecida como portal da Amazônia, devido sua localização portuária estratégica, assim como outras capitais, não demoraria muito para receber a doença. Nesse seguimento, a embarcação conhecida como vapor 
Ceará, vinda do Rio de Janeiro, atracou em Belém com tripulantes acometidos pelo vírus, sendo questão de tempo para que a doença se espalhasse pelo centro urbano de Belém. Conforme pode ser lido na obra Rastos e marcas das passadas minhas pelas sendas e avenidas da vida de Danilo Virgílio Mendonça.

A gripe espanhola chegou a Belém a bordo do navio "Ceará" no dia 05/10/1918, vindo do Sul do país após aportar dois dias antes em São Luis do Maranhão. Vistoriado pelo médico da "Saúde dos Portos" Dr. Lindolfo Campos de Acatauassú e pelo "Serviço Sanitário do estado", Drs. Sá Pereira, Mário Chermont, Ápio Medrado, Bernardes Rutowitz, Ciríaco Gurjão e Albino Cordeiro, foi o navio proibido de atracar no cais, tendo, entretanto, seus passageiros doentes permissão para desembarcarem, sendo todos isolados no Hospital São Roque. No dia 19/10/1918 chegou também o navio "Bahia". Um dos seus passageiros de nome Manoel Monteiro de Amoroso Lima hospedou-se no "Holtel América”, onde faleceu no dia 13/10. A gripe alastrou-se rapidamente e os jornais do dia 20/10 anunciavam que mais de 3.000 pessoas estavam gripadas. Em dezembro de 1918 já haviam falecido mais de 757 gripados (MENDONÇA, 2002, p. 67).

Com o avanço da doença no portal da Amazônia, ficou cada vez mais difícil para que os governantes escondessem a chegada do vírus, mesmo quando (em início do contágio) muitos descreviam a enfermidade como "gripezinha" na tentativa de não causar pânico na população. Enquanto isso, o narrador de Preces, Remédio Contra Epidemia relatava de forma ficcional que a doença não escolhia classe social, e que em alguns casos evoluía para o estado grave muito rápido, como se pode observar nesse trecho: "Ainda recordo o susto com que o grupo de minha adolescência, certa noite, recebeu a notícia que fôra enterrar Casemiro Pampolha Neves, companheiro e rapaz boníssimo que apenas há cinco dias desaparecera das nossas reuniões" (RIBEIRO, 2005, p. 71).

A crônica também descreve o avanço da doença, os boatos começavam a circular entre o povo, como a narrativa do peixeiro português, em que eram comuns as histórias de pessoas que eram enterradas vivas. $\mathrm{Na}$ trama, o peixeiro descreve a uma cliente, um acontecimento no necrotério da Santa Casa ${ }^{13}$, local em que salvou um primo de ser enterrado vivo. Naquela época muitas vítimas tinham que se enterradas as pressas devido à gravidade da doença, isso facilitava a o equívoco com os diagnósticos de óbito.

\footnotetext{
13. A Santa Casa da Misericórdia do Pará foi fundada em 24 de fevereiro de 1650. O hospital ficou conhecido por atender a população mais carente de Belém-PA, durante vários momentos em epidemias como de cholera-morbus, varíola, febre-amarela e da pandemia de gripe espanhola, em meados de 1918.
} 
Figura 4 - Fachada da Santa Casa de Misericórdia no início do século XX

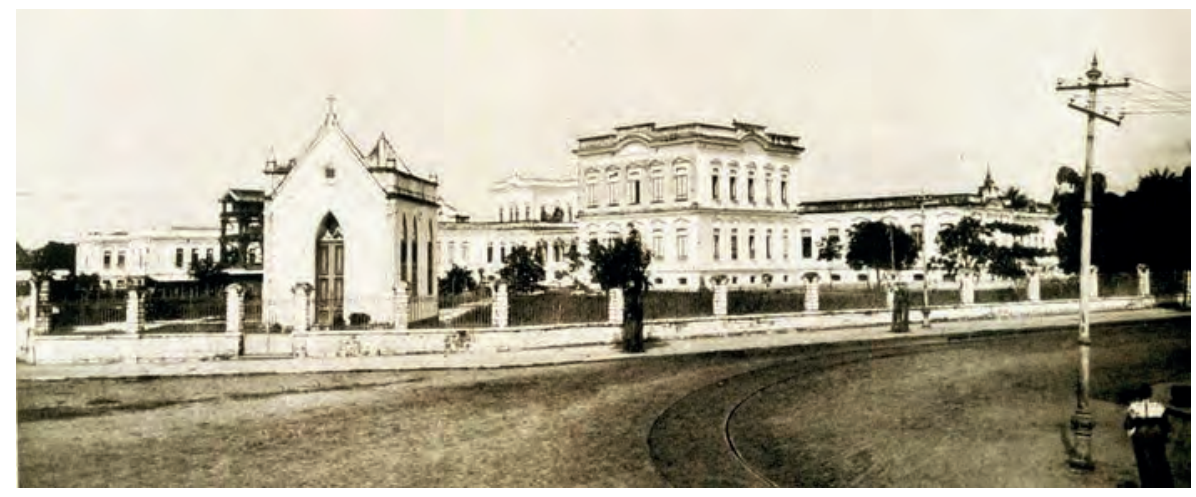

Fonte: Vianna (1902).

$\mathrm{Na}$ narrativa, o peixeiro descreve a uma cliente, um acontecimento no necrotério da Santa Casa, local em que salvou um primo de ser enterrado vivo. Nesse cenário, a autor atribui esses acontecimentos como uma história estarrecedora sobre a enfermidade. Além disso, é valido ressaltar que em meio ao caos, essa propagação de boatos de enterrarem as pessoas vivas, acabou gerando pânico entre a população belenense e um medo dos doentes procurarem os hospitais em busca por atendimento.

Surgiram histórias de estarrecer sobre a gripe. O peixeiro Português, que por mais de vinte anos era quem nos levava a porta a pescada amarela ou o camorim, a dez tostões a posta e quase sem gelo, contara a minha mãe ter retirado, quando já no "rabecão", entre outros mortos do necrotério da Santa Casa, que a carência de tempo não permitira "emperequitar", um seu primo que só assim escapara de ser levado à cova vivinho (RIBEIRO, 2005, p. 72).

No fragmento acima se observa que além da disseminação de rumores, mesmo em meio ao processo pandêmico, a população de menor poder aquisitivo não parou de trabalhar. O trabalhador informal colocado em questão representava não somente uma personagem na crônica de Campos Ribeiro, mas o proletariado de serviços essenciais, que se arriscavam pelo fato de não possuírem outros subsídios para se sustentarem. Além do mais, mesmo com a sensação de medo, muitos estabelecimentos se aproveitaram dos populares, o preço de vários itens teve um acréscimo repentino, principalmente em empreendimentos como supermercados e farmácias, o que acabou gerando ainda mais o aumento de vulnerabilidade socioeconômica e emocional de alguns cidadãos paraenses. 
Figura 5 - Conselhos da inspetoria de higiene

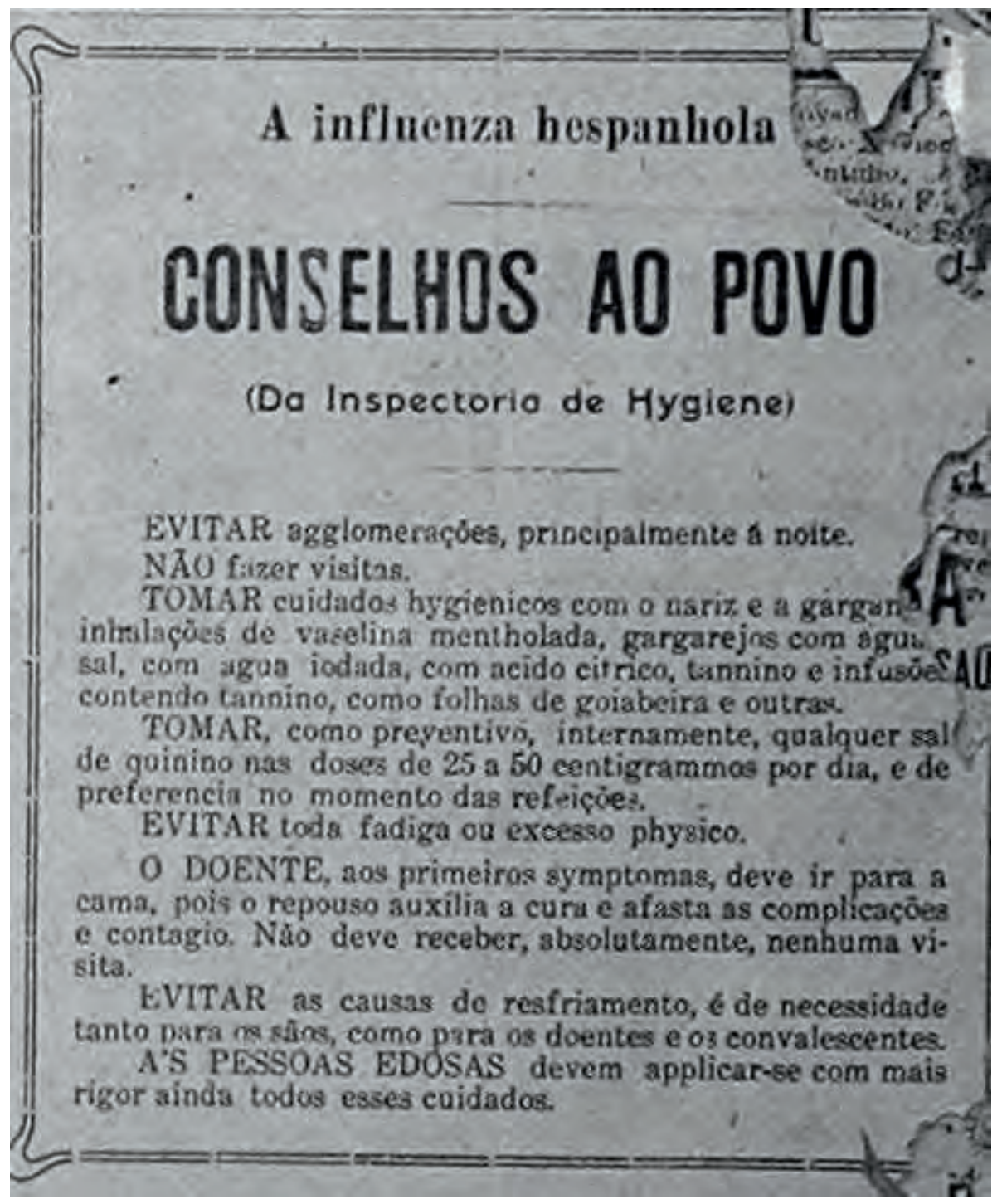

Fonte: Viégas (2011, p. 2).

Com o avanço da doença na cidade, uma série de medidas passou a fazer parte da rotina dos belenenses, como não se manifestar com apertos de mão, realizar visitas à doentes, tossir e não proteger a boca, bebidas geladas e alcoólicas, fazer aglomerações, velórios, beijo nas crianças e mais velho, dentre outras proibições Todas as medidas adotadas eram para frear entre a circulação do vírus entre a população. Além disso, assim como em outros países que fecharam 
estabelecimentos comerciais e escolas, o Brasil também tomou essa medida com o objetivo de não propagar o surto da "Hespanhola". Vários Estados brasileiros foram tomando esses decretos no decorrer do aumento do número de casos, na capital do Pará não foi diferente.

As medidas emergenciais para conter a propagação do vírus logo de início foram seguidas à risca entre a população, devido à sensação de medo e pavor que muitos se encontravam em ver tantos mortos em um curto espaço de tempo. Há inclusive inúmeros relatos de pessoas que entraram em depressão ou até mesmo se suicidaram devido ao clima de pavor, uma vez que, criou-se praticamente um "decreto" de que o diagnóstico da doença era uma sentença de morte.

O cronista Campos Ribeiro chega a demonstrar esse sentimento de trauma nas primeiras linhas da sua narrativa, assim como, o relaxamento dessas medidas de segurança com o passar dos meses, principalmente entre os jovens, no trecho ele discorre que "A rapaziada não dava grande importância aos estragos que a 'espanhola', então escrita com H, ia fazendo” (RIBEIRO, 2005, p. 71). É possível observar em outras linhas da narrativa, antes da proibição das aglomerações nos velórios, como a juventude se aproveitava desses episódios para outras finalidades, "Sabendo embora coisas assim, toda noite estava a turma à cata de um 'quarto' onde ninguém procurava saber quem era o defunto" (RIBEIRO, 2005, p. 72).

Havia "quarto"? Então haveria, logicamente, o pagode em que a mesa de jantar, no quintal, com lampião de carbureto alumiando, reuniria a turma da bisca, alheia às pequenas sapecas que, dentro da sala, estariam cuiras para um joguinho de prendas, com rápidas, furtivas saídas para os escurinhos de oitão, revesando-se, até, algumas delas, as preferências do parceiro, nunca o mesmo em reuniões seguidas... Uma por sinal, de tanta troca de par nessas fugas, ou em encontros outros, em esquinas propiciamente tenebrosas (às vezes, por duzentos réis a um garoto, uma lâmpada logo à tarde era quebrada a tiros de baladeira), ganhou o cognome, dado por velho e observador beberrão de taberna, ao se the referir aos assanhamentos: "a sôpa da canalha" (RIBEIRO, 2005, p. 72).

No trecho supracitado, percebe-se que os velórios eram verdadeiros pontos de encontros entre os jovens. O lugar era um ponto de reuniões para vários grupos, como a turma dos jogos, das paqueras, dos chamados beberrões, entre outros. $\mathrm{Na}$ verdade, eram verdadeiros pontos de disseminações da gripe espanhola, pela gravidade das situações ocorridas, uma vez que, muitos desses velórios possuíam inclusive vítimas do vírus. Nesse contexto, o narrador relata um episódio em que um "sapo" feito de lenço cai dentro de um caixão, levando 
aos presentes certo desconforto com o acontecido: “[...] E eis que, num dos lançamentos, caiu o "batráquio" dentro do caixão mortuário... Quem se atreveria tirá-lo dali? o impedimento não estava no cadáver, mas na doença que o levara, a pavorosa gripe!" (RIBEIRO, 2005, p. 72).

Percebe-se pelo ocorrido descrito pelo narrador, que mesmo com o descumprimento das medidas de segurança, no fundo as pessoas sabiam do risco que corriam nessas aglomerações nos famosos "quartos". Além do mais, é normal que o público jovem em um processo pandêmico, seja mais propenso a não se preocupar tanto com as recomendações dos órgãos governamentais da saúde. Nesse contexto, documentos e notícias da época relatam que o governo paraense tomou medidas ainda mais rígidas com o povo, como por exemplo, evitar que as famílias tivessem direito de velar o corpo e as visitas ao cemitério. Esse decreto contribuiu até mesmo para a revolta de algumas pessoas, uma vez que, é enraizado na cultura brasileira o "velar" do corpo de um ente querido. Inclusive esse foi um pivô de muito dos boatos que ocorriam na cidade, como o dos "enterrados vivos".

Nesse seguimento, o sentimento de pânico e medo fez com que uma parte da população "corresse" para o chamado "mundo espiritual", em busca da salvação, ou seja, se atrelou a idéia de sobrevivência ao vírus à alguma religião. Ademais, na literatura amazônica em geral, há muitos relatos do que esse sentimento de fé faz na vida do ser humano, temática esta que por algumas vezes se faz presente nos textos de literatura devido à formação cristã de boa parte da população paraense.

Há inúmeras histórias do imaginário paraense que estão marcadas nas páginas das obras de alguns escritores, como a da "Casa de Plácido", que conta a vida do agricultor paraense Plácido Souza, que encontrou a imagem de Nossa Senhora de Nazaré, o símbolo histórico e imortalizado do Círio de Nazarée ${ }^{4}$, sendo colocado como responsável de muitos milagres em diversas narrativas que versam relatos da realidade amazônica. Obras como o livro de O Carro dos Milagres, do escritor paraense Benedicto Monteiro (MONTEIRO, 1980) que traz narrativas em torno da importância da padroeira dos paraenses.

Além do Círio, que era um evento religioso já institucionalizado em Belém, durante Hespanhola, outras procissões foram organizadas

14 O Círio de Nazaré iniciou-se em 8 de setembro de 1793. A celebração é constituída por vários festejos, e leva todo ano no segundo domingo do mês de outubro, milhares de devotos e turistas para as ruas de Belém-PA. Em 2013, a festividade foi tombada como Patrimônio Cultural da Humanidade pela Unesco. 
espontaneamente pela população, que também as denominava de "preces". Estas alternativas de "diálogo com a doença" aconteceram com freqüência nos bairros da Cidade Velha e Umarizal, ainda que não incentivadas e até mesmo denunciadas pelos jornais como focos de aglomeração a serem combatidos, pois seriam responsáveis pela disseminação da infecção (ABREU JÚNIOR, 2018, p. 126).

Além do símbolo mais conhecido do catolicismo dos belenenses, outra parte da população procurava as reuniões e organizações de religiões protestantes como da Assembleia de Deus, instituição bastante conhecida também entre os populares, em virtude de terem início de seus trabalhos no país também em Belém do Pará. Nesse contexto, Campo Ribeiro relembra na narrativa às chamadas "preces", movimento dos adeptos do catolicismo. O narrador relata alguns momentos bastante peculiares que ocorriam durantes essas reuniões que aconteciam em vários pontos da capital do Pará, têm-se como o exemplo o trecho em que ele diz que: "Não só os quartos eram atração naqueles calamitosos dias. Mais divertidas e menos mórbidas as "preces"' (RIBEIRO, 2005, p. 73).

Com a proibição dos velórios, as preces passaram a servir como ponto de encontro para a juventude. O cronista relata que as procissões que percorriam as ruas, chamavam os rapazes e moças, para se juntar ao movimento com uma vela acesa. No entanto, é notório ressaltar que muitos jovens viam nessa oportunidade como uma medida de sair de casa e burlar as recomendações sobre aglomerações. O narrador discorre: "Que isso, isso, sim, era o objetivo de todos, já que qualquer mocinha à meia noite em casa corria por conta da "prece" (RIBEIRO, 2005, p. 73). Observa-se que isso evidencia como o movimento religioso era usado de justificativa para algumas situações de encontros que eram corriqueiras na mocidade daquela época.

As procissões serviam não só como o escape para a juventude, mas era também um lugar de refúgio para muitas aflições. Em muitos casos, a fé tornavase uma saída para a população, principalmente entre os mais pobres. É notório ver que as preces eram procissões majoritariamente entre as pessoas de menor poder aquisitivo, o autor em algumas linhas das crônicas menciona bairros periféricos de Belém, como o Jurunas ${ }^{15}$. Além disso, a rivalidade de alguns bairros, seja pelos clubes de futebol, carnaval, São João, entre outros eventos, também era refletida nesses cortejos, conforme pontua Ribeiro (2005, p. 73):

15 Um dos bairros mais populosos da cidade e de forte cultura carnavalesca, com forte devoção a imagem de Santa Teresinha do menino Jesus. 
$\mathrm{Na}$ Belém daqueles tempos estava no "clímax" a velha discórdia entre os bairros da cidade que se disputavam a liderança em tudo: Carnaval, São João e até no futebol, com a infância do São Domingos, jurunense, e clubes como Riachuelo, Pará Time, Onze Paraenses no Umarizal. Gente do Jurunas não ia com a que formava o "Martelos de Prata", o "Rouxinol", o "Canário", "Campineiro" não tolerava "cidadão".

No segmento acima se percebe que, a rivalidade de muitos acontecimentos culturais era também disseminada nas preces. O autor relata em algumas linhas que “Dai o 'sururu' em que degenerou certa noite, o 'encontro' de duas 'preces'. Uma do Umarizal ${ }^{16}$ da beata benzedeira de 'izipla' dona Helena” (RIBEIRO, 2005, p. 73). Observa-se também que os cortejos eram carregados de "ironias", visto que, as religiões têm em sua essência a propagação de amor e união, mas na pratica o fragmento apresentado pelo autor evidencia outro lado do ser humano, onde mesmo a situação da pandemia de gripe espanhola sobre a cidade, não era mais forte que vários ritos e costumes da população.

Mal desembocava a procissão a procissão na "Generalíssimo Deodoro", eis que surge, indo da "João Balbi", a outra "prece", a perigosa, cuja dona outra não era que Laura, façanhuda "cocote", figura constante nas crônicas policiais. E de repente, do grupo da Laura, o grito de muitos marmanjos: - "Ajoelha! Ajoelha!" (RIBEIRO, 2005, p. 74).

Esse confronto das chamadas preces era algo tão sério que chegou a ser comparado com a rivalidade dos bois-bumbás ${ }^{17}$ de alguns bairros da capital paraense. Certamente o narrador fez essa analogia por simbolizar a sensação que essa festa cultural na região norte transmite para as pessoas, uma vez que, em seu ideal inicial era para ser uma disputa saudável, entretanto, alguns cidadãos levaram para áreas além das culturais. É o caso do episódio dos cortejos de dona Helena e dona Laura, colocados em questão pelo narrador na passagem "a ordem, busca autoritária, pareceu aos devotos do Umarizal tão ofensiva quanto seria uma toada guerreira do 'Pai do Campo', o 'bumbá' do Jurunas, irreconciliável inimigo do 'Canário', coqueluche joanina de seu bairro” (RIBEIRO, 2005, p. 74).

Outra característica dessas procissões, é que os santos que eram referenciados tinham em sua essência alguma característica ligada à pandemia, os chamados santos protetores das pestes. $\mathrm{Na}$ crônica em umas das preces ocorre

16 Bairro nobre, localizado na região central da capital paraense.

17 O boi-bumbá é uma das festas folclóricas mais populares do Brasil, especialmente na região norte. Surgiu a partir do século XVII, advindo de uma lenda nordestina no conhecido período do gado. Na região amazônica teve atribuições da cultura indígena, obtendo características peculiares, como, por exemplo, a rivalidade intensa. 
o cortejo ao santo São Sebastião ${ }^{18}$, conhecido na história do catolicismo pela sua associação a momentos pandêmicos. Na História ocidental, em meados dos anos 680, há relatos que Roma enfrentava uma terrível epidemia, e o Bispo da época teve a ideia de trazer os restos mortais de São Sebastião, na intenção dos fiéis o invocar para que o surto pudesse ir embora. Incrivelmente, segundo alguns relatos, com a chegada dos ossos desse Mártir, a epidemia foi encerrada no país.

O caso é que subia pela "Boaventura da Silva", indo da "14 de Março", o povo crente de Dona Helena, que marchava imponente atrás do andor que decorara de papel dourado, levando, aos ombros de quatros moçoilas por ela escolhidas, bem bonitinhas e vestidas de branco, à imagem do glorioso São Sebastião (RIBEIRO, 2005, p. 73).

Compreende-se, na passagem acima, que a população belenense tinha toda uma organização em volta dos cortejos das procissões. Além do mais, assim como em outros países que utilizavam a devoção sobre o protetor das epidemias, São Sebastião. O povo da comunidade católica da capital paraense colocava muita esperança na fé e devoção, visto que, a cidade em sua essência é bem religiosa, e em casos excepcionais como desses momentos de surtos virais, é bem normal que a esperança seja depositada no divino. O narrador de Campos Ribeiro descreve um momento em que as vozes dos devotos subiam e evocavam em ardente súplica um dos cânticos do Santo da Epidemia: "Martir de cristo, meu Santo 'barão', livrai-nos da peste, São Sebastião!’ (RIBEIRO, 2005, p. 73).

Salienta-se que a gripe "hespanhola" coincidiu com o declínio do período da borracha em Belém, expondo ainda mais a distinção das classes sociais, mudando costumes que eram rotineiros na capital. O "novo normal" não foi nada fácil para algumas pessoas, pois o vírus deixou perdas irreparáveis, de ente queridos, de empregos, de empreendimentos, entre muitos outros setores da sociedade. As preces e os velórios, acontecimentos no qual, a população se aglomerava, deixaram muitas histórias, marcando a vida de muitos indivíduos, sejam pelos episódios cômicos dos cortejos religiosos, ou até mesmo, pelas brincadeiras da mocidade que aconteciam nos velórios de várias vítimas da espanhola. No entanto, sem dúvidas o número de mortos não só no Pará, mas em

18 São Sebastião é tido como protetor de pestes e doenças contagiosas. Era um soldado do exército de Roma, que foi torturado por professar sua fé, não renegando Jesus Cristo. Foi associado a momentos epidêmicos da sociedade, como nas cidades de Milão, em 1575 e Lisboa em 1599, que foram acometidas por surtos virais, e que devido à intercessão ao Santo se viram livres. O Santo tem orações e muitos cânticos conhecidos pelos adeptos do catolicismo. Sendo inclusive padroeiro da cidade do Rio de Janeiro. 
outros estados brasileiros, foram o marco mais marcante da pandemia. Ribeiro (2005, p. 74) relata que:

Depois que a "espanhola" se foi (que Deus a mandasse pras profundas!) continuou benzendo "izipla", com o galhinho de arruda passando em cruz, em cima da "vermelha", o puro azeite doce com sal - "o que eu corto?" e recebendo a resposta do paciente: - "Izipla...".

E com sua saia de alpaca preta, seu "matinée" de "étamine", seus sapatos abotinados, entrando quando em vez na taberna, para pedir, junto ao gradil onde se enfileiravam as garrafas da embiiba, da laranjinha, da anizeta, sua lambada de purinha.

- "Bota aí um tostão de contrariedade!....".

O fragmento acima relata o momento do "retorno à normalidade" na sociedade belemense, mas, a gripe hespanhola revelou mazelas do povo e confrontos internos jamais imagináveis. A humanidade teve aprender a se reinventas diante de muitas mudanças, tanto no aspecto psíquico como social. Campos Ribeiro (2005) escreveu muito mais do que só uma narrativa de caráter memorialística, mas também apresentou uma capital do Pará de múltiplos aspectos, destacando dilemas enraizados culturalmente na rotina dos paraenses, e apresentando uma cidade que escondia atrás de uma rica arquitetura europeia, mas com problemas significativos que iam além do vírus da gripe espanhola. Como pode ser lido no trecho repetido duas vezes na narrativa - "Bota aí um tostão de contrariedade" (RIBEIRO, 2005, p. 73) - revelando uma Belém dizimada e dividida pela moléstia que causou tantas contradições sociais.

\section{CONSIDERAÇÕES FINAIS}

A crônica Preces, Remédio Contra Epidemia, de Campos Ribeiro revela toda a experiência de vida do autor ligada ao legado jornalístico adquirido por anos de atividade jornalística, mas principalmente a sua memória individual engrenada á uma biografia que também é coletiva da cidade de Belém. O que nos leva a pensar nas palavras de Bosi (1994) ao questionar: qual é a forma predominante de memória de um dado indivíduo? O único modo correto de sabê-lo é levar o sujeito a fazer sua autobiografia. A narração da própria vida é o testemunho mais eloqüente dos modos que a pessoa tem de lembrar. É a sua memória.

Diante do que foi exposto, o que se pode pensar sobre as memórias de pandemia que já acometeram a população das civilizações do mundo? O que os brasileiros, em especial, os amazônidas aprenderam com as epidemias? 
Respondendo à pergunta, talvez quase nada. A situação da epidemia da gripe hespanhola e da atual pandemia da covid-19 parecem que em nada "ensinaram" ou irão ensinar alguns seres humanos, pois estes parecem não terem entendido e atendido as súplicas dos cientistas em manter a normas de controle dos vírus.

Passado e presente conversam por meio não só de narrativas ficcionais, mas por cenas reais, em que a vida parece perder o valor. A negação à ciência e o descontrole com as medidas de circulação de ambos os vírus (gripe espanhola e covid-19) demonstraram novamente o quanto estamos aquém de nos tornarmos uma sociedade solidária e evoluída.

\section{REFERÊNCIAS}

ABREU JUNIOR, J. M. C. O vírus e a cidade: rastros da gripe espanhola no cotidiano da cidade de Belém (1918). Belém: Paka-Tatu, 2018.

BOSI, E. Memória e sociedade: lembranças de velhos. 3a ed. São Paulo: Companhia das Letras, 1994.

CROSBY, A. W. American forgotten pandemic: the influenza of 1918. New York: Cambridge University Press, 1989.

JURANDIR, D. Passagem dos Inocentes. 2. ed. Belém: Falângola, 1984.

LUCENA, F. Coronavírus já matou mais que a Gripe Espanhola no Rio de Janeiro. DiariodoRio.com., Rio de Janeiro, 25 ago. 2020. História. Disponível em: https://diariodorio.com/coronavirus-ja-matou-mais-que-a-gripeespanhola-no-rio-de-janeiro/. Acesso em: 26 ago. 2020.

MEIRA, O, Memórias do quase ontem. Rio de Janeiro: Lidador, 1976.

MENDONÇA, D. V. Rastos e marcas das passadas minhas pelas sendas e avenidas da vida. Belém: Sagrada Família, 2002.

MONTEIRO, B. O carro dos milagres. 2. ed. Rio de Janeiro. Nova cultura: PLG Comunicação, 1980.

O NOVO coronavirus e o que pandemias anteriores tem a nos ensinar.

UFSM, Santa Maria, 27 abr. 2020. CCSH. Disponível em: https://www.ufsm. br/unidades-universitarias/ccsh/2020/04/27/o-novo-coronavirus-e-o-quepandemias-anteriores-tem-a-nos-ensinar/. Acesso em: 19 abr. 2021. 
POTTER, C. W. A history of influenza. J. Appl. Microbiol., [S. l.], v. 91, n. 4, p. 572-579, 2001.

RIBEIRO, J. S. C. Gostosa Belém de outrora... Belém: SECULT/PA, 2005.

SMITH JUNIOR, F. P. Imigração espanhola na Amazônia: as colônias agrícolas e o desenvolvimento socioeconômico do nordeste paraense (1890-1920). 2012. 212 f. Tese (Doutorado em Ciências: Desenvolvimento Socioambiental) - Programa de Pós-Graduação em Desenvolvimento Sustentável do Trópico Úmido, Núcleo de Altos Estudos Amazônicos, Universidade Federal do Pará, Belém, 2012.

VIANNA, A. O. N. A santa casa de misericórdia paraense: notícia histórica (1650-1902). Typographia de Alfredo Augusto Silva, Belém, Pará, 1902.

VIÉGAS, H. Belle Époque amazônica. Realidades Urbanas, Belém, 04 mar. 2011. Disponível em: http:/ / realidadeurbanas.blogspot.com/2011/03/belleepoque-amazonica.html. Acesso em: 22 ago. 2020. 
